\title{
Soluble-fibre concentrate lowers plasminogen activator inhibitor-1 in baboons (Papio ursinus)
}

\author{
BY C. S. VENTER ${ }^{1}$, C. J. NEL ${ }^{1}$, H. H. VORSTER ${ }^{1}$, J. C. JERLING ${ }^{1}$, W. OOSTHUIZEN ${ }^{1}$, \\ F. J. VELDMAN ${ }^{1}$, J. A. KELLERMAN ${ }^{1}$, C. M. SMUTS $^{2}$, W. J. H. VERMAAK ${ }^{3}$, \\ D. G. VAN DER NEST ${ }^{1}$ AND J. H. DE RIDDER ${ }^{4}$ \\ ${ }^{1}$ Nutrition Research Group, Potchefstroom University, Potchefstroom, South Africa \\ ${ }^{2}$ National Research Programme for Nutritional Intervention, Tygerberg, South Africa \\ ${ }^{3}$ Department of Chemical Pathology, University of Pretoria, South Africa \\ ${ }^{4}$ Department of Biokinetics, Potchefstroom University, Potchefstroom, South Africa
}

(Received 8 July 1996 - Revised 14 February 1997 - Accepted 17 February 1997)

\begin{abstract}
The effects of a soluble NSP (fibre) concentrate (SFC) on plasma fibrinogen and plasminogen activator inhibitor-1 (PAI-1), serum and liver lipids and lipoproteins and glucose tolerance were compared with those of bezafibrate (BF), a lipid-lowering drug, in obese baboons (Papio ursinus). The basal diet was a high-fat (37\% of total energy), low-NSP $(12.4 \mathrm{~g} / \mathrm{d})$ Westernized diet, supplemented for 8 weeks with either $20 \mathrm{SFCg} / \mathrm{baboon}$ per d or $6.7 \mathrm{mg}$ BF/kg body weight per baboon per d. SFC supplementation significantly lowered PAI-1, total serum cholesterol, HDLcholesterol and circulating free fatty acid levels. BF significantly lowered total serum cholesterol, but unexpectedly raised serum triacylglycerol levels. Although not statistically significant, the mean liver tricacylglycerol concentration of baboons fed on BF was lower than that of baboons fed on SFC supplements. These results suggest that: (1) the mechanism of action of the two cholesterol-lowering treatments differ, with BF having a liver triacylglycerol-lowering effect and (2) the SFC had additional beneficial effect on fibrinolysis by lowering PAI-1 levels.
\end{abstract}

Soluble-fibre concentrate: Plasminogen activator inhibitor-1: Baboons

Cardiovascular disease accounts for approximately one in every three deaths in Western societies. Increased plasma concentrations of cholesterol, fibrinogen (Wilhemsen et al. 1984; Meade et al. 1986; Kannel et al. 1987), tissue plasminogen activator inhibitor (PAI1; Hamsten et al. 1985; Juhan-Vague et al. 1989) and insulin (Fontbonne \& Eschwege, 1987) are independent risk markers of arterial disease. In human subjects as well as nonhuman primates, abnormalities in haemostasis and carbohydrate and lipid metabolism are often present in the same individual and commonly associated with android (central) obesity (Reaven, 1988; Landin et al. 1990a; Bodkin et al. 1993). Genetic as well as environmental factors such as diet and physical activity seem to play a role in the development of these disturbances.

Patients under free-living conditions often find it difficult to comply with diet regimens. Therefore, supplementing the diet of human subjects and experimental animals with NSP concentrates such as konjac-glucomannan (KGM), guar gum or oat husk has been tested and reported to be effective in lowering serum total cholesterol (TC; Vorster et al. 1985; Venter et al. 1987; Avrill \& Boden, 1995), improving glucose tolerance (Jenkins et al. 1980; Vorster \& de Jager, 1984; Vorster et al. 1988), lowering plasma fibrinogen 
(Koepp \& Hegewisch, 1981; Vorster et al. 1985; Venter et al. 1991) and PAI-1 activity (Sundell \& Rånby, 1993; Brown et al. 1995).

Treatment with hypolipidaemic drugs is frequently prescribed to patients who do not respond adequately to dietary recommendations. Among such drugs, fibrates have been widely used for many years. Bezafibrate (BF), one of the new derivatives of clofibrate, is a well-tolerated drug with effective hypolipidaemic properties and has the ability to lower raised plasma fibrinogen (Stahlberg, 1992). Fibrate treatment reduces PAI-1 levels in hypertriacylglycerolaemic patients in whom triacylglycerol (TAG) levels are normalized (Keber et al. 1994).

The objective of the present investigation was to compare, under controlled conditions of dietary intakes, the effects of a Westernized diet supplemented with a soluble-fibre concentrate (SFC) and BF on plasma haemostatic variables, serum lipid profile, liver lipid content, glucose tolerance and immunoreactive insulin response in the baboon (Papio ursinus) model. The SFC granules used in the present study contained 600 g KGM and $400 \mathrm{~g}$ other soluble NSP (pectin and agar) $/ \mathrm{kg}$, produced by the Tsuruta Shokuhin Company of Japan and distributed by the Mannan Life Company (Birchacres Pharmacy, Kempton Park, South Africa). KGM is a highly-viscous hemicellulose which consists of a linear polymer of mannose and glucose. According to Southgate (1976) the mannose: glucose value is between 1:1 and 2.4:1. It is obtained from the tubers of Amorphophallus konjac (K. Koch) and has been used in Japan for centuries in the form of Konnyako (Ebihara et al. 1981).

\section{MATERIALS AND METHODS}

Animals, experimental design and diets

Twenty healthy adult male baboons weighing 24.1 (SD 3.2) $\mathrm{kg}$ were studied. All procedures were approved by the Ethics Committee of the Potchefstroom University. The baboons were caged individually in our laboratory animal centre, allowed to stablize for 8 weeks, treated for internal parasites with Ivomectum ${ }^{\circledR}$ (Logosagved, Halfway House, Johannesburg, South Africa; $1 \mathrm{ml} / 50 \mathrm{~kg}$ ), fed one orange daily and ad libitum a non-purified diet designed for horses (Excella ${ }^{\circledR}$; Senwesco, Viljoenskroon, South Africa). The baboons had free access to tap water. For the next 8 weeks the baboons were fed on a Westernized diet consisting of $200 \mathrm{~g}$ white-bread sandwiches with $20 \mathrm{~g}$ margarine (Floro ${ }^{\circledR}$; Vandenberg Foods (Pty) Ltd, Durban, South Africa), $20 \mathrm{~g}$ syrup (Illovo ${ }^{\circledR}$; CG Smith Sugar Ltd, Natal, South Africa), $40 \mathrm{~g}$ peanut butter (Yum-Yum ${ }^{\circledR}$; Premier Food Industries Ltd, Killarney, South Africa), $80 \mathrm{~g}$ shortbread (Eet-Sum-Mor ${ }^{\circledR}$; Bakers Ltd, Pinetown, South Africa), $30 \mathrm{~g}$ plain chocolate (Nestlé SA (Pty) Ltd, Randburg, South Africa), $100 \mathrm{~g}$ dog biscuits (Brakenjan ${ }^{\circledR}$ no. V9796; Senwesco) and $80 \mathrm{~g}$ fruit (orange and apple). The nutrient analysis was done by computer using local food tables (Langenhoven et al. 1991). Carbohydrates supplied $51 \%$ of the total energy of the diet, protein $12 \%$ and fat $37 \%$.

The baboons were then randomly assigned to two groups of ten each, and baseline measurements were taken. The mean weight of the baboons differed significantly from the pre-study weight and both groups were considered as obese (Table 1). An increase in waist: hip as well as significant increases in subscapular skinfolds indicated android obesity. For the next 8 weeks group 1 was fed on bezafibrate $(6.7 \mathrm{mg} / \mathrm{kg}$ body weight per baboon per d; BF Bezalip Retard ${ }^{\circledR}$; Boehringer Mannheim, Mannheim, Germany) and the Westerrized diet described previously. Group 2 was fed on the same diet plus $20 \mathrm{~g}$ soluble NSP concentrate (Mannan Life dietary fibre; Mannan Life Company) per baboon perd. The NSP supplement and crushed BF tablets were mixed with the margarine, syrup and 
peanut butter and spread onto the bread. Food intake was recorded every second day. The nutrient composition of the food consumed by the two groups is indicated in Table 2. After 8 weeks, final measurements were taken before the baboons were killed.

\section{Blood and liver samples}

The $2 \mathrm{~h}$ glucose tolerance tests (GTT) were performed at baseline and after 8 weeks of hypolipidaemic treatment. The baboons were fasted for $12 \mathrm{~h}$ before the GTT were done. All the tests were performed between 08.00 and 11.00 hours in the laboratory animal centre. The baboons were immobilized with ketamine $(1 \mathrm{mg} / \mathrm{kg}$ body weight; Kyron Laboratories (Pty) Ltd, Benrose, Johannesburg, South Africa), weighed on an electronic scale and anthropometric measurements were taken. Crown-rump length was measured with the baboons in the supine position on a calibrated ruler with a fixed head rest. Skinfold thicknesses were determined with a John Bull skinfold caliper (British Indicators Ltd, London) and circumferences with a steel tape. For skinfold and circumference measurements specific anatomical landmarks on the skeleton were identified to standardize the measurements. Thereafter, the baboons were anaesthetized with sodium pentobarbitone (1 mg/kg; Sagatal ${ }^{\circledR}$; Rhône-Poulênc, Pretoria, South Africa) given intravenously. A solution of $1 \mathrm{~g}$ glucose in $5 \mathrm{ml}$ water/ $\mathrm{kg}$ body weight was administered via a stomach tube. Venous blood samples were taken for the measurement of glucose, insulin, fibrinogen, PAI-1, albumin and lipids before the GTT and 30, 60, 90 and 120 min thereafter for the measurement of glucose and insulin. An intravenous catheter (Jelco, Johnson \& Johnson, Halfway House, South Africa) was used. The catheter was placed in the vena cephalica. Blood $(10 \mathrm{ml})$ for the preparation of serum was collected in the fasting state, and $5 \mathrm{ml}$ at each time period during the GTT. Fasting citrate-treated plasma samples for the determination of fibrinogen concentration and PAI-1 activity were prepared by mixing one part of a buffered $0.1 \mathrm{~mol}$ sodium citrate/l solution (cat. no. ORKH G98 01219; Behring, Marburg, Germany; $\mathrm{pH} 4.5-4.9$ ) and nine parts of venous blood. Blood samples were centrifuged at $4000 \mathrm{rev} . / \mathrm{min}$ within $15 \mathrm{~min}$. Serum and plasma were stored in portions at $-72^{\circ}$ for later analyses. A balanced solution of electrolytes (Ringer's lactate equivalent, Plasmalyte $B^{\circledR}$ from Normosol R; Abbott Laboratories, Johannesburg, South Africa) was administered intravenously from the start of the GTT in order to perform 120 min GTT. Additional doses of pentobarbitone were necessary during the $2 \mathrm{~h}$, but care was taken to keep the total amount the same for a particular baboon during the two GTT performed on each baboon. Finally, each baboon was given a lethal dose of pentobarbitone, livers were excised quickly, blotted dry and weighed. Samples were frozen in physiological saline $(9 \mathrm{~g} \mathrm{NaCl} / 1)$ solution to prevent frost-bite and kept at $-70^{\circ}$ until analysed.

\section{Serum and plasma analyses}

Serum TC, TAG and glucose were determined using the SMAC ${ }^{\mathrm{TM}}$ Technicon AutoAnalyzer, (model SRA 2000; Technicon Instrument Co. Ltd, Tarry Town, NY, USA). The clinical chemistry methods of Technicon Instrument Co. Ltd were routinely used with observance of the standard quality-assurance measures. Serum HDL-cholesterol (HDL-C) and free fatty acid (FFA) were determined by enzymic colorimetric methods (cat. no. 263869 and 1082914 respectively; Boehringer Mannheim). Plasma fibrinogen concentration was determined by a modification of the method of Clauss (1957) using a Fibrintimer and reagents from Behring Institute (cat. no. OTXG 21; Marburg, Germany). PAI-1 activity was measured by an indirect enzymic method (Spectrolyse ${ }^{\mathbb{B}} / \mathrm{pl} \mathrm{PAI}$, cat. 
Table 1. The effect of a Westernized diet supplemented with bezafibrate $(B F)$ or soluble-fibre concentrate (SFC) on anthropometric measurements in baboons (Papio ursinus)

(Mean values and standard deviations)

\begin{tabular}{|c|c|c|c|c|}
\hline \multirow{2}{*}{$\begin{array}{l}\text { Treatment group } * . . . \\
\text { Variable }\end{array}$} & \multicolumn{2}{|c|}{$1(\mathrm{BF})$} & \multicolumn{2}{|c|}{$2(\mathrm{SFC})$} \\
\hline & Mean & SD & Mean & SD \\
\hline \multicolumn{5}{|l|}{ Body wt $(\mathrm{kg})$} \\
\hline Pre-study & $30 \cdot 3^{\mathrm{a}}$ & 3.5 & $29.8^{\mathrm{b}, \mathrm{c}}$ & 3.3 \\
\hline Baseline & $31.8^{\mathrm{a}}$ & $2 \cdot 1$ & $32 \cdot 5^{\mathrm{c}, \mathrm{d}}$ & 2.7 \\
\hline Final & 32.3 & 2.0 & $33 \cdot 8^{b, d}$ & 3.3 \\
\hline \multicolumn{5}{|c|}{ Crown-rump length (m) } \\
\hline Pre-study & 0.76 & 0.04 & 0.77 & 0.02 \\
\hline Baseline & 0.76 & 0.04 & 0.78 & 0.01 \\
\hline Final & 0.78 & 0.03 & 0.77 & 0.02 \\
\hline \multicolumn{5}{|l|}{ BMI ${ }^{+}$} \\
\hline Pre-study & $53 \cdot 1^{\mathrm{a}}$ & 7.4 & $50 \cdot 0^{\mathrm{b}, \mathrm{c}}$ & 3.9 \\
\hline Baseline & 54.9 & 7.5 & $53 \cdot 8^{\mathrm{b}, \mathrm{d}}$ & $4 \cdot 1$ \\
\hline Final & $53.4^{\mathrm{a}}$ & 3.0 & $56 \cdot 6^{\mathrm{c}, \mathrm{d}}$ & 4.7 \\
\hline \multicolumn{5}{|l|}{ Neck skinfold (mm) } \\
\hline Pre-study & $5.9^{\mathrm{a}}$ & 1.2 & $5 \cdot 0^{\mathrm{b}}$ & 1.4 \\
\hline Baseline & $4 \cdot 3^{\mathrm{a}, \mathrm{c}}$ & 1.0 & $4 \cdot 4^{\mathrm{d}}$ & 0.5 \\
\hline Final & $6.5^{\mathrm{c}}$ & 1.1 & $7 \cdot 4^{\mathrm{b}, \mathrm{d}}$ & 1.9 \\
\hline \multicolumn{5}{|c|}{ Subumbilical skinfold (mm) } \\
\hline Pre-study & $8 \cdot 5$ & $2 \cdot 1$ & $7 \cdot 1^{\mathrm{a}, \mathrm{b}}$ & $2 \cdot 3$ \\
\hline Baseline & 9.4 & 1.8 & $11.4^{\mathrm{b}}$ & 5.0 \\
\hline Final & 10.9 & 2.6 & $9.8^{\mathrm{a}}$ & 3.7 \\
\hline \multicolumn{5}{|c|}{ Subscapular skinfold (mm) } \\
\hline Pre-study & $5 \cdot 4^{\mathrm{a}, \mathrm{b}}$ & 1.2 & $5 \cdot 3^{\mathrm{c}}$ & 0.9 \\
\hline Baseline & $6 \cdot 4^{\mathrm{a}, \mathrm{d}}$ & 0.9 & $6.6^{\mathrm{c}, \mathrm{e}}$ & $1 \cdot 1$ \\
\hline Final & $8 \cdot 8^{\mathrm{d}, \mathrm{b}}$ & 1.7 & $8.4^{e}$ & 1.7 \\
\hline \multicolumn{5}{|c|}{ Upper abdominal skinfold (mm) } \\
\hline Pre-study & $5 \cdot 2^{\mathrm{a}, \mathrm{b}}$ & 1.0 & $4 \cdot 8^{c, d}$ & 1.0 \\
\hline Baseline & $8 \cdot 1^{\mathrm{a}}$ & 1.5 & $7.5^{\mathrm{d}}$ & 1.6 \\
\hline Final & $8.8^{\mathrm{b}}$ & 1.4 & $8 \cdot 4^{\mathrm{c}}$ & $1 \cdot 3$ \\
\hline \multicolumn{5}{|c|}{ Abdominal circumference $(\mathrm{mm})$} \\
\hline Pre-study & $558^{\mathrm{a}, \mathrm{b}}$ & 30 & $532^{\mathrm{c}, \mathrm{d}}$ & 40 \\
\hline Baseline & $629^{\mathrm{a}}$ & 45 & $621^{a}$ & 65 \\
\hline Final & $628^{b}$ & 51 & $638^{\mathrm{c}}$ & 51 \\
\hline \multicolumn{5}{|c|}{ Hip circumference $(\mathrm{mm})$} \\
\hline Pre-study & $700^{\mathrm{a}}$ & 30 & $683^{\mathrm{c}}$ & 30 \\
\hline Baseline & $761^{a, d, b}$ & 54 & $691^{\text {b.e }}$ & 49 \\
\hline Final & $707^{\mathrm{d}}$ & 24 & $721^{\mathrm{c}, \mathrm{e}}$ & 33 \\
\hline \multicolumn{5}{|l|}{ Waist:hip } \\
\hline Pre-study & $0.79^{\mathrm{b}}$ & 0.03 & $0.78^{\text {a.c }}$ & 0.06 \\
\hline Baseline & 0.83 & 0.08 & $0.89^{\mathrm{a}}$ & 0.09 \\
\hline Final & $0.89^{\mathrm{b}}$ & 0.06 & $0.89^{\mathrm{c}}$ & 0.07 \\
\hline
\end{tabular}

a,b,c,d,e Means in a row with the same superscript letters were significantly different $(P<0.05)$.

* For details of diets and procedures, see pp. 626-627.

$\dagger$ Body wt $(\mathrm{kg}) \div$ crown-rump length $^{2}$ ( $\mathrm{m}^{2}$; Kemnitz et al. 1989).

no. 101201; Biopool, Umeå, Sweden). The appropriate internal and external standards were used in all instances. The CV of repeated PAI-1 measurements was $3.5 \%$. Serum insulin levels were determined using a radioimmunological kit (Phadeseph; Pharmacia Diagnostics $\mathrm{AB}$, Uppsala, Sweden). Insulin sensitivity index was calculated as the reciprocal of fasting insulin $\times$ glucose multiplied by 10000 (Donahue et al. 1988). The incremental glucose area above the fasting or other lowest value observed during the GTT was calculated. 
Table 2. The effects of a Westernized diet supplemented with bezafibrate $(B F)$ or soluble-fibre concentrate (SFC) on daily nutrient intakes of baboons (Papio ursinus)

\begin{tabular}{|c|c|c|}
\hline $\begin{array}{l}\text { Treatment group*.... } \\
\text { Nutrient }\end{array}$ & $1(\mathrm{BF})$ & $2(\mathrm{SFC})$ \\
\hline Total energy: $\mathrm{kJ}$ & 6361 & 7736 \\
\hline kcal & 1514 & 1865 \\
\hline Total protein (g) & $46 \cdot 1$ & $56 \cdot 6$ \\
\hline Plant protein (g) & 43.4 & 53.8 \\
\hline Animal protein (g) & 2.7 & 2.7 \\
\hline Protein (\% energy) & $12 \cdot 3$ & $12 \cdot 2$ \\
\hline Total fat $(\mathrm{g})$ & 61.1 & 76.6 \\
\hline Saturated fatty acids $(\mathrm{g})$ & 21.3 & $24 \cdot 1$ \\
\hline Polyunsaturated fatty acids (g) & 7.7 & 15.8 \\
\hline Monounsaturated fatty acids (g) & $19 \cdot 3$ & 24.6 \\
\hline Fat (\% energy) & 36.5 & $37 \cdot 1$ \\
\hline Cholesterol (mg) & 53.6 & 53.6 \\
\hline Total carbohydrates (g) & 191.5 & 238.0 \\
\hline Carbohydrates (\% energy) & 51.2 & 51.2 \\
\hline Sugar $(\mathrm{g})$ & $44 \cdot 3$ & 54.3 \\
\hline Fibre $(\mathrm{g})$ & 9.1 & 12.4 \\
\hline $\mathrm{Ca}(\mathrm{mg})$ & $270 \cdot 3$ & $321 \cdot 2$ \\
\hline $\mathrm{Fe}(\mathrm{mg})$ & 9.3 & 10.6 \\
\hline $\mathrm{Mg}(\mathrm{mg})$ & 99.3 & 149.7 \\
\hline$P(\mathrm{mg})$ & 351.8 & $482 \cdot 6$ \\
\hline $\mathrm{K}(\mathrm{mg})$ & 707.8 & 944.6 \\
\hline $\mathrm{Na}(\mathrm{mg})$ & 1164.0 & 1754.6 \\
\hline $\mathrm{Zn}$ (mg) & $3 \cdot 1$ & 4.3 \\
\hline $\mathrm{Cu}(\mathrm{mg})$ & 0.1 & 1.5 \\
\hline Mn (mg) & 1.8 & $2 \cdot 4$ \\
\hline Vitamin A (RE) & 518.4 & $576 \cdot 3$ \\
\hline Thiamin (mg) & 0.7 & 0.8 \\
\hline Riboflavin (mg) & 0.8 & 0.8 \\
\hline Niacin $(\mathrm{mg})$ & 7.3 & $10 \cdot 2$ \\
\hline Vitamin $B_{6}(\mathrm{mg})$ & 0.5 & $0 \cdot 6$ \\
\hline Folate $(\mu \mathrm{g})$ & 88.6 & 123.8 \\
\hline Pantothenic acid (mg) & $2 \cdot 1$ & 2.5 \\
\hline Biotin $(\mu \mathrm{g})$ & 3.4 & 4.2 \\
\hline Vitamin C (mg) & 42.4 & 42.4 \\
\hline Vitamin D $(\mu \mathrm{g})$ & 0.8 & 1.2 \\
\hline Vitamin E (mg TE) & 9.8 & $15 \cdot 1$ \\
\hline Additional soluble NSP ( $\mathrm{g}$ ) & - & 20.0 \\
\hline
\end{tabular}

$\mathrm{TE}$, tocopherol equivalents.

* For details of diets and procedures, see pp. 626-627.

\section{Liver analysis}

The liver samples were stored at $-70^{\circ}$ until analysed. After the samples were thawed, portions of the liver were snap-frozen with liquid $\mathrm{N}_{2}$ and immediately ground to a fine powder, and weighed for protein and lipid analysis (Smuts et al. 1992). For lipid extraction, the tissue was first suspended in $0.5 \mathrm{ml}$ saline and extracted with chloroform-methanol $(2: 1, \mathrm{v} / \mathrm{v}$; Folch et al. 1957) containing butylated hydroxytoluene $(0.1 \mathrm{ml} / \mathrm{l})$ as antioxidant. A portion of the lipid extraction was then used for fatty acid, cholesterol, TAG and total phospholipid analysis.

Fatty acid analysis. The lipid extracts were fractionated by TLC as described by Skipski et al. (1965), using diethyl ether-light petroleum (b.pt. $40-60^{\circ}$ )-acetic acid (30:90:1, by vol.) to separate the neutral lipids. The plates were sprayed with chloroform- 
methanol $(1: 1, \mathrm{v} / \mathrm{v})$ containing 2,5 -bis-5'-tert-butylbenzoxazolyl-[2'] thiophene and the spots visualized under u.v. light. The spots corresponding to TAG and total phospholipids were marked, scraped off and transferred to glass-stoppered tubes. Fatty acids were transmethylated with $2.5 \mathrm{ml}$ methanol-11.6 M-sulfuric acid $(95: 5, \mathrm{v} / \mathrm{v})$ at $70^{\circ}$ for $2 \mathrm{~h}$, as described by Smuts et al. (1992). The resultant fatty acid methyl esters were analysed using a Varian model 3700 gas chromatograph (Varian, Palo Alto, CA, USA) using fused silica megabore DB-225 columns (cat. no. 125-2232; J\&W Scientific, Folsom, CA, USA). The individual fatty acid methyl esters were identified by comparison of the retention times with those of a standard mixture of FFA $\mathrm{C}_{14: 0}$ to $\mathrm{C}_{22: 6}$.

Phospholipid determination. The total phospholipid concentrations were determined colorimetrically with malachite green dye (Itaya \& Ui, 1966) after digestion with perchloric acid (16 M) at $170^{\circ}$ for $2 \mathrm{~h}$.

Cholesterol and triacylglycerol determinations. Lipid extracts were emulsified with peroxide-free Triton X100, as described by Smuts et al. (1992), before analysis. TC and unesterified cholesterol from the emulsified lipid extracts were determined by an enzymic iodide method using cholesterol oxidase $(E C$ 1.1.3.6) and cholesterol esterase (EC 3.1.1.13) enzymic preparations. The concentration of cholesteryl ester (CE) was obtained by subtraction. The TAG concentrations were measured by an enzymic colorimetric method (Peridochrom GPO-PAP, cat. no. 701 882; BM, Germany).

Protein determination. The powdered liver preparations $(10-15 \mathrm{mg})$ were first digested with $\mathrm{NaOH}$ and SDS at $37^{\circ}$. The protein content was determined using a modification of the Lowry method (Markwell et al. 1978).

\section{Statistical analysis}

Significant differences between groups were determined using Student-Newman-Keuls and Tukey tests (ANOVA, general linear model). Within groups, between baseline and final values, differences were analysed using paired Student's $t$ tests. Pearson correlation coefficients were also calculated. All analyses were done using Statsoft ${ }^{\circledR}$ CSS: Statistica software (Statsoft Inc., 1996). $P<0.05$ was considered significant.

\section{RESULTS}

The addition of SFC made no difference to the acceptability of the diet and caused no side effects. Mean energy intake of the baboons in group 2 (SFC) was $184.9 \mathrm{~kJ} / \mathrm{kg}$ body weight. However, the bitter taste of $\mathrm{BF}$ in the sandwiches resulted in reduced intake. Of the sandwiches offered to the baboons $62 \%$ were consumed. Consequently, the mean BF intake was only $4.2 \mathrm{mg} / \mathrm{kg}$. Fruit, shortbread and chocolate were accepted very well, and the dog biscuits fairly well. Mean daily energy intake of the baboons in group $1(\mathrm{BF})$ was $175.8 \mathrm{~kJ} /$ $\mathrm{kg}$. The mean weight of the baboons increased somewhat, as shown in Table 1. The mean increase of $1.3 \mathrm{~kg}$ in group 2 was statistically significant. However, the mean weight of the two groups did not differ from each other. Waist:hip increased in group 1 as result of a decrease in hip circumference. The subscapular skinfold thickness, which also correlates with android obesity (Donahue et al. 1987), increased significantly in both groups.

The mean serum TC and LDL-C concentrations of both groups were significantly $(P<0.05)$ raised by the Westernized diet relative to the low-fat, high-fibre diet fed during the stablilizing period, while the concentration of TAG remained constant in group 2 but decreased significantly $(P<0.05)$ in group 1 from a mean pre-study value of 0.81 (SD 0.41$)$ to 0.53 (SD 0.19 ) $\mathrm{mmol} / \mathrm{l}$. After 8 weeks of supplementation with SFC and BF, the mean serum TC concentration was significantly lower in both groups (Table 3). The LDL-C 
concentration followed the same pattern, but the changes were not significant. There was a significant decrease in the HDL-C concentration in the baboons fed on SFC, but the percentage of TC as HDL-C in both groups was higher than baseline value $(P<0.05$ in group 1). The mean TAG concentration remained the same in group 2. However, an unexpected statistically significant increase in TAG was observed in group 1, the same baboons in which the Westernized stabilizing diet resulted in a decrease in TAG levels. SFC supplementation resulted in significantly lower FFA levels. In both groups, the albumin concentration increased, although the increase was not significant.

As shown in Table 3, the mean PAI-1 activity was significantly reduced in the SFCsupplemented group but increased by BF (not significant). Plasma fibrinogen concentration remained remarkably constant during the stabilizing phase as well as during the experimental phase. The increase in albumin resulted in an increase in the

Table 3. The effects of a Westernized diet supplemented with bezafibrate $(B F)$ or soluble-fibre concentrate (SFC) on serum lipids, lipoproteins, albumin and plasma haemostatic variables for baboons (Papio ursinus)

\begin{tabular}{|c|c|c|c|c|}
\hline \multirow{2}{*}{$\begin{array}{l}\text { Treatment group } \neq . . . \\
\text { Variable }\end{array}$} & \multicolumn{2}{|c|}{$1(\mathrm{BF})$} & \multicolumn{2}{|c|}{$2(\mathrm{SFC})$} \\
\hline & Mean & SD & Mean & SD \\
\hline \multicolumn{5}{|l|}{$\mathrm{TC}(\mathrm{mmol} / \mathrm{l})$} \\
\hline Baseline & 3.22 & 0.50 & $3 \cdot 25$ & 0.48 \\
\hline Final & $2.86^{*}$ & 0.33 & $2.67 *$ & 0.49 \\
\hline \multicolumn{5}{|l|}{ LDL-C $(\mathrm{mmol} / \mathrm{l})$} \\
\hline Baseline & 1.23 & 0.19 & 1.23 & 0.36 \\
\hline Final & 1.07 & 0.41 & 1.14 & 0.30 \\
\hline \multicolumn{5}{|l|}{ HDL-C $(\mathrm{mmol} / \mathrm{l})$} \\
\hline Baseline & 1.81 & 0.41 & 1.81 & 0.30 \\
\hline Final & 1.73 & 0.40 & $1.58^{*}$ & 0.26 \\
\hline \multicolumn{5}{|c|}{ HDL-C (mmol/100 mmol TC) } \\
\hline Baseline & $55 \cdot 72$ & 5.62 & 55.40 & 4.88 \\
\hline Final & $60.42 *$ & 10.35 & 60.03 & 8.86 \\
\hline \multicolumn{5}{|l|}{$\mathrm{TAG}(\mathrm{mmol} / \mathrm{l})$} \\
\hline Baseline & 0.53 & 0.19 & 0.71 & 0.44 \\
\hline Final & $0.74 *$ & 0.29 & 0.71 & 0.35 \\
\hline \multicolumn{5}{|l|}{$\mathrm{FFA}(\mathrm{mmol} / \mathrm{l})$} \\
\hline Baseline & 0.14 & $0 \cdot 10$ & 0.15 & $0 \cdot 10$ \\
\hline Final & 0.16 & 0.60 & $0.08 *$ & 0.04 \\
\hline \multicolumn{5}{|l|}{ Albumin $(g / l)$} \\
\hline Baseline & 39.8 & 4.0 & 36.9 & 2.6 \\
\hline Final & 43.7 & $5 \cdot 2$ & $38.4 \uparrow$ & 4.6 \\
\hline \multicolumn{5}{|l|}{ Fibrinogen $(g / 1)$} \\
\hline Baseline & $2 \cdot 1$ & 0.4 & $2 \cdot 1$ & 0.3 \\
\hline Final & $2 \cdot 0$ & 0.4 & 2.0 & 0.4 \\
\hline \multicolumn{5}{|c|}{ PAI-1 activity (units/ml) } \\
\hline Baseline & $5 \cdot 1$ & 3.7 & 7.5 & 3.9 \\
\hline Final & $10 \cdot 2$ & $12 \cdot 2$ & $4.8 *$ & 3.1 \\
\hline \multicolumn{5}{|l|}{ Albumin : fibrinogen } \\
\hline Baseline & $19 \cdot 0$ & $10 \cdot 0$ & 17.6 & 8.7 \\
\hline Final & 21.9 & $13 \cdot 0$ & 19.2 & 11.5 \\
\hline
\end{tabular}

TC, total serum cholesterol: LDL-C, LDL-cholesterol; HDL-C, HDL-cholesterol; TAG, triacylglycerols; FFA, free fatty acids; PAI-1, plasminogen activator inhibitor-1.

Mean final values were significantly different from baseline values, within groups (paired $t$ tests): ${ }^{*} P<0.05$.

Mean value for group 2 (SFC) was significantly different from that group 1 (BF) (ANOVA, general linear model): $+P<0.05$.

$\ddagger$ For details of diets and procedures, see pp. 626-628. 


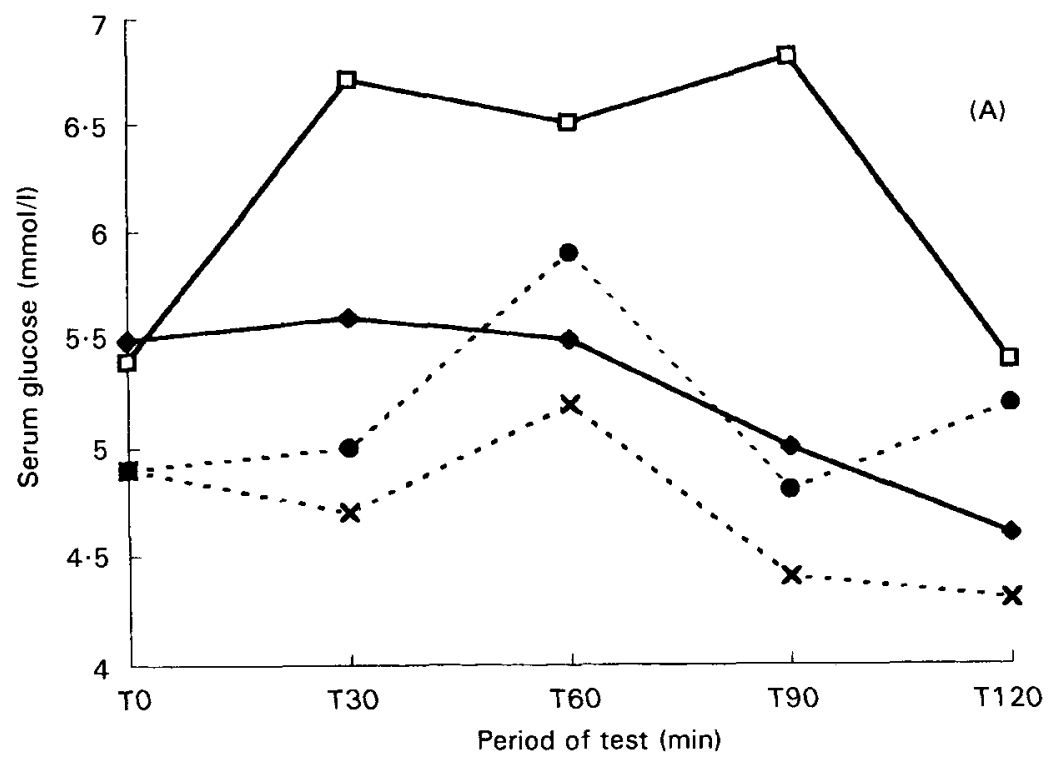

(B)

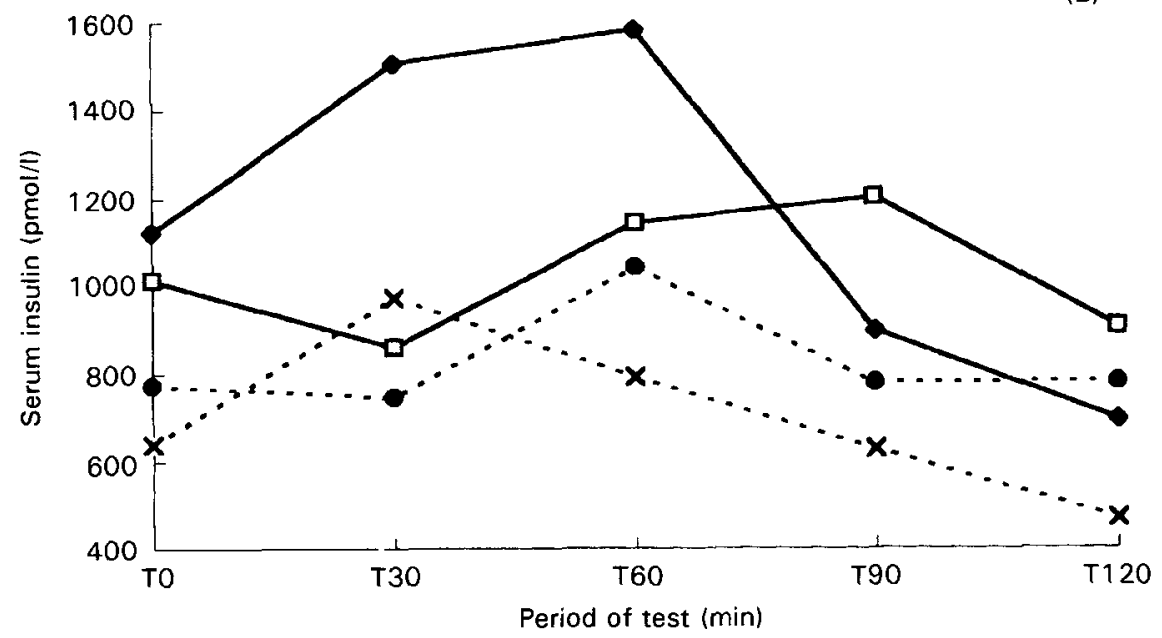

Fig. 1. The effect of a Westernized diet supplemented with bezafibrate (BF; group 1 ) or soluble-fibre concentrate (SFC; group 2) on mean serum glucose (A) and insulin (B) values during $2 \mathrm{~h}$ glucose tolerance tests in baboons (Papio ursinus). Mean baseline fasting insulin in group 2 was significantly different from that for group $1(P<0 \cdot 05)$. ( $\bullet)$, BF, baseline; $(\square)$, BF, final; $(\times)$, SFC, baseline; $(\bigcirc)$, SFC, final. For details of diets and procedures, see pp. $626-628$.

albumin : fibrinogen value in both groups. It has been shown that low albumin levels affect the fibrinolytic system by modifying fibrin clot structure (Grandrille \& Aiach, 1990).

No significant changes due to the different treatments were observed in fasting serum glucose or insulin, maximum increments in glucose or insulin during the $2 \mathrm{~h}$ GTT, calculated insulin sensitivity index and area under the glucose and insulin curves 
(Fig. 1). There was considerable inter-individual variation in serum insulin levels. We have previously noted this variation in serum insulin levels among baboons (Venter et al. 1990) and are now reconsidering the suitability of the baboon for studies of glucose metabolism. In the present study, the mean baseline fasting serum insulin concentration as well as the maximum insulin increment of the BF-treated group was almost double that of the SFCsupplemented group (1121 (SD 573) pmol/1 v. 639 (SD 398) pmol/l and 990 (SD 796) pmol// v. $509(\mathrm{SD} 481) \mathrm{pmol} / \mathrm{l}$ respectively; $P<0.05)$. In the BF-treated group, the area under the glucose curve did not change (baseline 11.5 (SD 8.6) $\mathrm{mmol} / \mathrm{l}$ per min and final value 11.9 (SD 9.0) $\mathrm{mmol} / 1$ per min) whilst the area under the insulin curve decreased remarkably (1051 (SD 716) pmol/1 per min $v .690$ (SD 713) pmol/1 per min) and the calculated insulin sensitivity index improved from 2.0 (SD 0.9) to 2.3 (SD 1.4) (not significant). In the SFCsupplemented group, the area under the glucose curve increased from 7.9 (SD 4.7) to 10.1 (SD 9.8) $\mathrm{mmol} / \mathrm{l}$ per min but the area under the insulin curve remained constant (baseline 572 (SD 460) and final 518 (SD 561) pmol/l per min) and insulin sensitivity index decreased from 4.7 (SD 3.2) to 3.8 (SD 2.4).

The liver concentrations of TAG, cholesterol and phospholipids were lower (not significant) in the group which received BF than in the SFC supplemented group (86.2 (SD 60.7), 30.4 (SD 5.7) and 317.9 (SD 40.5) $\mathrm{mg} / \mathrm{g}$ protein $v .122 .1$ (SD 100.7), 33.1 (SD 3.4) and 340 (SD 36.1 ) $\mathrm{mg} / \mathrm{g}$ protein respectively). The only significant difference between the two groups was in the amount of docosahexaenoic acid $\left(\mathrm{C}_{22: 6}\right)$, which was higher in group 1 (BF; 58 (SD 9) mol/100 mol total fatty acids in phospholipids) than in group 2 (SFC; 47 (SD 6) $\mathrm{mol} / 100 \mathrm{~mol}$ total fatty acids in phospholipids).

\section{DISCUSSION}

Significant reductions in PAI-1 have been reported in healthy subjects after changing from a traditional Western diet to a low-fat, high-fibre (35-46 g NSP/4200 kJ) diet (Mehrabian et al. 1990). Furthermore, supplementing the habitual diet of healthy volunteers with oat husk (Sundell \& Rånby, 1993) or guar gum (Landin et al. 1992) decreased PAI-1 activity. KGM-supplements had the same effect in nephrectomized rats (Brown et al. 1995). The mechanism whereby the gel-fibre supplement used in the present study (a mixture of glucomannan, pectin and agar) decreased PAI-1 activity is not clear. PAI-1 activity has been shown to be positively correlated with insulin concentrations and degree of insulin resistance (Landin et al. 1990b). Soluble NSP improves insulin sensitivity in diabetic patients (Koepp \& Hegewisch, 1981; Vorster et al. 1988), healthy men (Landin et al. 1992) and nephrectomized Sprague-Dawley rats (Brown et al. 1995). However, insulin sensitivity in baboons was not improved by the SFC in the present study and could not have been the reason for the decrease in PAI-1 activity. The positive correlation between PAI-1 and serum TAG concentration which has been reported repeatedly (Mehta et al. 1987), was not observed in our study. However, liver TAG concentration of the baboons was positively correlated with PAI-1 activity $(P<0.05, r 0.7)$. Modest weight loss reduces PAI-1 levels (Sundell et al. 1989), but the mean body weight of the baboons was significantly increased by the SFC-supplemented diet.

Very little is known about the influence of diet on coagulation and fibrinolysis. Studies done in hospitals in the UK showed that the incidence of post-operative venous thrombosis could be reduced by feeding patients high-NSP diets (Frohn, 1976; Latto, 1976). Simpson et al. (1982) reported improvement in some coagulation factors in diabetic subjects who increased their intake of NSP, mainly as leguminuous vegetables. They failed to demonstrate an effect on fibrinogen levels. However, Koepp \& Hegewisch (1981) reported 
decreased plasma viscosity and fibrinogen levels in diabetic children after supplementation of their diet with guar gum. Supplementing a Westernized diet fed to baboons with KGM lowered fibrinogen and factor X concentrations (Vorster et al. 1985). Guar gum and KGM are both water-soluble NSP which are readily fermented by bacteria in the large gut to the short-chain fatty acids (SCFA) acetic, propionic and butyric acid.

The possibility that SCFA may have an inhibitory effect on blood coagulation was first mentioned by Malhotra (1968), an Indian physician who found longer mean clotting time and softer, jelly-like clots in men in Udaipur, North India, in comparison with men in Madras in South India who ate less cellulose and vegetable fibres.

The mechanism whereby SCFA may influence the coagulation system is not clear. Studies in human subjects indicate that acetate, the major SCFA produced in the colon, passes to peripheral tissues, where it is metabolized by muscle (Cummings et al. 1988). Butyrate is largely taken up by colonic epithelial cells and propionate is cleared by the liver. Reeder et al. (1993) demonstrated in vitro that sodium butyrate alters the balance of components of the plasminogen activator system favourably. It is further possible that by stimulating glycolysis (Anderson \& Bridges, 1984) and inhibiting the release of fatty acids (Chen et al. 1984), propionate may inhibit the synthesis of fibrinogen and other coagulation factors in the liver. Pilgeram \& Pickart (1968) suggested that raised circulating FFA levels stimulate fibrinogen synthesis. In the present study, the mean fibrinogen concentration decreased by $5 \%$ in both groups but the change was not significant. The BF dose could have been too small to be effective. However, the amount of SFC fed to the baboons in the present study was the same as that used in the previous study (Vorster et al. 1985). Fibrinogen concentration of the baboons in the present study was in the normal range, which is probably difficult to improve. Although not statistically significant, serum albumin concentration increased in both groups, resulting in a higher albumin:fibrinogen value. As mentioned earlier, low albumin concentrations may alter the structure of fibrin clots and reduce thrombolysis (Gandrille \& Aiach, 1990). Khodabandehlou \& Le Devehat (1990) suggested that the albumin:fibrinogen value indicates the erythrocyte aggregation tendency and, therefore, the haemorheological risk.

$\mathrm{BF}$ is an effective lipid-lowering agent in human subjects as well as in animal models (Stahlberg, 1992). The recommended dosage of the sustained formulation is $400 \mathrm{mg} / \mathrm{d}$ (6.7 $\mathrm{mg} / \mathrm{kg}$ for an adult weighing $60 \mathrm{~kg}$ ). The same dose was given to the baboons. However, because of the bitter taste the mean intake was only $4.2 \mathrm{mg} / \mathrm{kg}$ body weight per d. Marked species differences between rats, mice, guinea-pigs, hamsters, rabbits, dogs and monkeys in hepatic response to BF have been reported (Watanabe et al. 1989). Compared with the $10 \mathrm{mg} / \mathrm{kg}$ body weight perd administered intragastrically by Stegmeier et al. (1980) to normolipidaemic non-human primates, the dose in our study might have been too small to lower TAG. A significant dose-response relationship for plasma cholesterol and TAG concentrations has been reported for BF (Stahlberg, 1992).

The present study showed that $4.2 \mathrm{mg} \mathrm{BF} / \mathrm{kg}$ body weight daily for 8 weeks reduced serum TC and LDL-C concentrations by $11 \%(P<0.05)$ and $13 \%$ (not significant) respectively in baboons. HDL-C tended to be lower than baseline values and serum TAG rose significantly, but liver lipid concentration tended to be lower in BF-treated animals than in the group fed on SFC. The availability of fatty acids has a strong influence on the rate of TAG and VLDL production by the liver (Kissebah et al. 1974; Catapano 1992). However, Karhapää et al. (1992) reported no change in FFA levels during BF treatment of patients with combined hyperlipidaemia. In contrast to the inability of BF to change fasting serum FFA in the baboons, SFC supplementation reduced FFA markedly $(P<0.05)$, an effect which has previously been observed in baboons (Venter et al. 1990). The 
hypocholesterolaemic effect of soluble dietary fibres, as observed in the present study, is well known (Arvill \& Boden, 1995). However, SFC had no beneficial effect on indices of glucose metabolism in the baboons. Although insulin sensitivity was improved to some extent by BF, and insulin response during the GTT reduced, we did not notice any significant changes in indices of glucose metabolism. Therefore, our findings suggest that low doses of BF do not change insulin sensitivity in baboons. Karhapää et al. (1992) came to the same conclusion with regard to insulin sensitivity in subjects with combined hyperlipidaemia and normal glucose tolerance.

In conclusion, both interventions had beneficial effects on the CHD risk profile in the baboon model, whilst the SFC had more pronounced effects. It seems that the effects of BF were mediated through the liver. It is recommended that subjects at risk of developing CHD and patients with confirmed CHD (with the exception of familial hypercholesterolaemia) should increase their intake of soluble NSP before medication is considered. No side effects were observed in the baboons fed on SFC; on the contrary, the increases in body weight and in daily energy intake from the diet were somewhat higher than those in the BF-supplemented group. NSP concentrates may be used effectively in the treatment of the metabolic syndrome associated with android obesity. However, the effect of SFC on haemostatic balance needs to be confirmed and possible mechanisms need to be identified.

The authors are grateful to the South African Medical Research Council for their financial support, and to Boehringer Mannheim who kindly supplied the bezafibrate.

\section{REFERENCES}

Anderson, J. W. \& Bridges, S. R. (1984). Short-chain fatty acid fermentation products of plant fiber affect glucose metabolism of isolated rat hepatocytes. Proceedings of the Society for Experimental Biology and Medicine 177, 372-376.

Arvill, A. \& Boden, L. (1995). Effect of short-term ingestion of konjac glucomannan on serum cholesterol in healthy men. American Journal of Clinical Nutrition 61, 585-589.

Bodkin, M. L., Hannah, J. S., Ortmeyer, J. K. \& Hansen, B. C. (1993). Central obesity in rhesus monkeys: association with hyperinsulinemia, insulin resistance and hypertriglyceridemia? International Journal of Obesity 17, 53-61.

Brown, M., Venter, C. S., Vorster, H. H., Jerling, J. C., Oosthuizen, W. \& van der Nest, D. G. (1995). Dietary fibre decreases some cardiovascular risk markers in an uremic rat model. South African Journal of Clinical Nutrition 8, 7-11.

Catapano, A. L. (1992). Mode of action of fibrates. Pharmacology Research 26, 331-340.

Chen, W. J. L., Anderson, J. W. \& Jennings, D. (1984). Propionate may mediate the hypocholesterolemic effects of certain soluble plant fibres in cholesterol-fed rats. Proceedings of the Society for Experimental Biology and Medicine 175, 215-218.

Clauss, A. (1957). Gerinnungsphysiologishe Schnellmethode zur bestimming des Fibrinogens (Rapid method of clotting physiology for the characterization of the fibrinogens). Acta Haematologica 17, 237-246.

Cummings, J. H., Pomare, E. W., Branch, W. J., Naylor, C. P. E. \& MacFarlane, G. T. (1988). Short chain fatty acids in human large intestine, portal, hepatic and venous blood. Gut 28, 1221-1227.

Donahue, R. P., Abbott, R. D., Bloom, E., Reed, D. M. \& Yano, J. (1987). Central obesity and coronary heart disease in men. Lancet $\mathbf{i}, 987-988$.

Donahue, R. P., Orchard, T. J., Becker, D. J., Kuller, L. H. \& Drash, A. L. (1988). Physical activity, insulin sensitivity, and the lipoprotein profile in young adults: the Beaver County study. American Journal of Epidemiology 127, 95-103.

Ebihara, K., Masuhara, R. \& Kiriyama, S. (1981). Effect of konjac-mannan, a water soluble dietary fiber, on plasma glucose and insulin responses in young men undergoing glucose tolerance tests. Nutrition Reports International 23, 577-583.

Folch, J., Lees, M. \& Sloane-Stanley, G. H. (1957). A simple method for the isolation and purification of total lipides from animal tissues. Journal of Biological Chemistry 226, 497-509.

Fontbonne, A. \& Eschwege, E. (1987). Diabetes, hyperglycaemia, hyperinsulinaemia and atherosclerosis: epidemiological data. Diabete et Metabolisme 13, 350-353.

Frohn, M. J. N. (1976). Left leg varicose veins and deep-vein thrombosis. Lancet ii, 1019-1020. 
Gandrille, S. \& Aiach, M. (1990). Albumin concentration influences fibrinolytic activity in plasma and purified systems. Fibrinolysis 4, 225-232.

Hamsten, A., Wiman, B., de Faire, U. \& Blombäck, M. (1985). Increased plasma levels of a rapid inhibitor of tissue plasminogen activator in young survivors of myocardial infarction. New England Journal of Medicine 313, 1552-1563.

Itaya, K. \& Ui, M. (1966). A new micromethod for the colorimetric determination of inorganic phosphate. Clinica Chimica Acta 14, 361-366.

Jenkins, D. J. A., Wolever, T. M. S., Nineham, R., Sarson, D. L., Bloom, S. R., Ahern J., Alberti, K. G. M. \& Hockaday, T. D. R. (1980). Improved glucose tolerance four hours after taking guar with glucose. Diabetologia 19, 21-24.

Juhan-Vague, I., Alessi, M. C., Joly, P., Thirion, X., Vague, P., Declerck, P. J., Serradimigni, A. \& Collen, D. (1989). Plasma plasminogen activator inhibitor-1 in angina pectoris. Influence of plasma insulin and acutephase response. Arteriosclerosis 9, 362.

Kannel, W. B., D'Agostino, R. B. \& Belanger, A. C. (1987). Fibrinogen, cigarette smoking and risk of cardiovascular disease: insights from the Framingham study. American Heart Joumal 113, 1006-1010.

Karhapää, P., Uusitupa, M., Voutilainen, E. \& Laasko, M. (1992). Effects of bezafibrate on insulin sensitivity and glucose tolerance in subjects with combined hyperlipidemia. Clinical Pharmacology and Therapeutics $\mathbf{5 2}$, $620-626$.

Keber, I., Lavre, J., Suc, S \& Keber, D. (1994). The decrease of plasminogen activator inhibitor after normalization of triglycerides during treatment with fibrates. Fibrinolysis 8, 57-59.

Kemnitz, J. W., Goy, R. W., Flitsch, T. J., Lohmiller, J. J. \& Robinson, J. A. (1989). Obesity in male and female rhesus monkeys: fat distribution, glucoregulation and serum androgen levels. Journal of Clinical Endocrinology and Metabolism 69, 287-293.

Khodabandehlou, T. \& Le Devehat, C (1990). Role of albumin and fibrinogen on red cell aggregation disaggregation in diabetes mellitus. Clinical Hemorheology 10, 557-560.

Kissebah, A. H., Adams, P. W., Harrigan, P. \& Wynn, V. (1974). The mechanism of action of clofibrate and tetranicotinoylfuctose (bradilan) on the kinetics of plasma free fatty acid and triglyceride transport in type IV and type V hypertriglyceridaemia. European Journal of Clinical Investigation 4, 163-174.

Koepp, P \& Hegewisch, S. (1981). Effects of guar on plasma viscosity and related parameters in diabetic children. European Journal of Pediatrics 137, 31-33.

Landin, K., Holm, G., Tengborn, L. \& Smith, U. (1992). Guar gum improves insulin sensitivity, blood lipids, blood pressure, and fibrinolysis in healthy men. American Journal of Clinical Nutrition 56, 1061-1065.

Landin, K., Stigendal, L. \& Eriksson, E. (1990a). Abdominal obesity is associated with an impaired fibrinolytic activity and elevated plasminogen activator inhibitor 1. Metabolism 39, 1044-1048.

Landin, K., Tengborn, L. \& Smith, U. (1990b). Elevated fibrinogen and plasminogen activator inhibitor (PAI-1) in hypertension are related to metabolic risk factors for cardiovascular disease. Journal of Internal Medicine 227, 273-278.

Langenhoven, M., Kruger, M., Gouws, E. \& Faber, M. (1991). MRC Food Composition Tables. Parow: MRC.

Latto, C. (1976). Postoperative deep-vein thrombosis, pulmonary embolism, and high-fibre diet (letter). Lancet ii, 1197 .

Malhotra, S. L. (1968). Studies on blood coagulation, diet, and ischaemic heart disease in two population groups in India. British Heart Journal 30, 303-308.

Markwell, M. A. K., Haas, S. M., Bieber, L. L. \& Tolbert, N. E. (1978). A modification of the Lowry procedure to simplify protein determination in membrane and lipoprotein samples, Analytical Biochemistry 87, 206-210.

Meade, T. W., Brozovic, M., Chakrabarti, R. R., Haines, A. P., Imeson, J. D., Mellows, S., Miller, G. J., North, W. R. S., Stirling, Y. \& Thompson, S. B. (1986). Haemostatic function and ischaemic heart disease: principal results of the Northwick Park Heart Study. Lancet ii, 533-537.

Mehrabian, M., Peter, J. B., Barnard, R. J. \& Lusis, A. J. (1990). Dietary regulation of fibrinolytic factors. Atherosclerosis 84, 25-32.

Mehta, J., Mehta, P., Lawson, D. \& Saldeen, T. (1987). Plasminogen activator inhibitor levels in coronary artery disease: correlation with age and serum triglyceride concentrations. Journal of the American College of Cardiology 9, 263-268.

Pilgeram, L. O. \& Pickart, L. R. (1968). Control of fibrinogen bio-synthesis: the role of free fatty acid. Atherosclerosis Research 8, 155-166.

Reaven, G.-M. (1988). Role of insulin resistance in human disease. Diabetes 37, 1595-1607.

Reeder, J. A., Dickinson, J. L., Chenevix-Trench, G. \& Antalis, T. M. (1993). Sodium butyrate differentially modulates plasminogen activator inhibitor type-1, urokinase plasminogen activator, and its receptor in a human colon carcinoma cell. Teratogenesis Carcinogenesis Mutagenesis 13, 75-88.

Simpson, H. C. R., Mann, J. I., Chakrabarti, R., Imeson, J. D., Stirling, Y., Tozer, M., Woolf, L. \& Meade, T. W. (1982). Effect of high fibre diet on haemostatic variables in diabetes. British Medical Journal 284, 1608.

Skipski, V. P., Smolowe, A. F., Sullivan, R. C. \& Barclay, M. (1965). Separation of lipid classes by thin-layer chromatography. Biochimica et Biophysica Acta 106, 386-396. 
Smuts, C. M., Kruger, M., van Jaarsveld, P. J., Fincham, J. E., Schall, R., van der Merwe, K. J. \& Benadé, A. J. S. (1992). The influence of fish oil supplementation on plasma lipoproteins and arterial lipids in ervet monkeys with established atherosclerosis. Prostaglandins Leukotrienes \& Essential Fatty Acids 47, 129 138.

Southgate, D. A. T. (1976). The chemistry of dietary fibre. In Fibre in Human Nutrition, pp. 31-72 [G. A. Spiller and R. J. Amen, editors]. New York: Plenum.

Stahlberg, D. (1992). Effects of bezafibrate - a hypolipidemic drug. Cardiovascular Drug Reviews 10, $259-279$.

Statsoft Inc. (1996) STATISTICA for Windows. Tulsa, OK: Statsoft Inc.

Stegmeier, K., Stork, H., Lenz, H., Leuschner, F. \& Liede, V. (1980). Pharmacology and mode of action of bezafibrate in animals. In Lipoproteins and Coronary Heart Disease, pp. 76-82 [H. Greten, P. D. Lang and G. Schettler, editors]. Baden-Baden, Germany: Gerhard Witzstrock Publishing House.

Sundell, I. B., Dahlgren, S., Rånby, M., Lundin, E., Stenling, R \& Nilson, T. K. (1989). Reduction of elevated plasminogen activator inhibitor levels during modest weight loss. Fibrinolysis 23, 45-50.

Sundell, I. B. \& Rånby, M. (1993). Oat husk fiber decreases plasminogen activator inhibitor type 1 activity. Haemostasis 23, 45-50.

Venter, C. S., Kruger, H. S., Vorster, H. H., Serfontein, W. J., Ubbink, J. B. \& de Villiers, L. S. (1987). The effects of the dietary fibre component konjac-glucomannan on serum cholesterol levels of hypercholesterolaemic subjects. Human Nutrition: Food Science and Nutrition 41F, 55-61.

Venter, C. S., Vorster, H. H. \& van der Nest, D. G. (1990). Comparison between physiological effects of konjac-glucomannan and propionate in baboons fed western diets. Journal of Nutrition 120, 1046-1053.

Venter, C. S., Vorster, H. H., van der Nest, D. G. \& Wight, A. W. (1991). Effects of konjac-glucomannan and propionate on plasma fibrinogen and serum and liver lipids in Zucker rats. South African Journal of Clinical Nutrition 4, 6-11.

Vorster, H. H. \& de Jager, J. (1984). The effect of the long-term ingestion of konjac-glucomannan on glucose tolerance and immunoreactive insulin values of baboons. South African Medical Journal 65, 805-808.

Vorster, H. H., Kruger, H. S., Frylinck, S., Botha, B. J., Lombaard, W. A. \& de Jager, J. (1985). Physiological effects of the dietary fibre component konjac-glucomannan in rats and baboons. Journal of Plant Foods 6 , 263-274.

Vorster, H. H., Venter, C. S., van Eeden, T. S., Silvis, N., Huisman, H. W., van Ryssen, J. C. J. \& Walker, A. R. P. (1988). Benefits from supplementation of the current recommended diabetic diet with gel fibre. International Clinical Nutrition Review 8, 140-146.

Watanabe, T., Horie, S., Yamada, J., Isaji, M., Nishigaki, T., Naito, J. \& Suga, T. (1989). Species differences in the effects of bezafibrate, a hypolipidemic agent, on hepatic peroxisome-associated enzymes. Biochemical Pharmacology 38, 367-371.

Wilhelmsen, L., Svärdsudd, K., Korsan-Bengsten, K., Larsson, B., Welin, L \& Tibblin, G. (1984). Fibrinogen as a risk factor for stroke and myocardial infarction. New England Journal of Medicine 311, 501-505. 